\title{
The Nature of the Court's "Jurisdiction" in Statutory Arbitration Post-Award Motions
}

\author{
Francis E. Jones, Jr.*
}

The unstated premise of any discussion of judicial review of arbitration awards ${ }^{1}$ is one's answer to this question: What ought to be the respective roles of the arbitrator and the courts ${ }^{2}$ in the process of decision-making by mutual private volition? Who is to give the answer-initially and ultimately -is of more practical consequence than what the answer is or should be. Historically the answer was given by the courts. ${ }^{3}$ More recently the legislature has purported to settle the question by incorporating special provisions regarding judicial review into the modern arbitration statutes. These modern statutes typically enumerate grounds for vacating or modifying awards and establish a summary motion procedure to confirm and enter

* Associate Professor of Law, University of Southern California. This article is a part, in altered form, of a thesis to be submitted to the law school of Yale University in partial satisfaction of requirements for the J.S.D. degree.

1 Various studies have been made and statistics gathered concerning the incidence of judicial review of arbitration awards. Estimates vary, but there is a good deal of agreement that the percentage of awards contested in court is extremely low. See AMERICAN BAR AssociaIIon, Labor Reiations Law 80; Procedural and Substantive Aspects of Labor-Management Arbitration, 12 ARB. J. (n.s.) 67 (American Arbitration Association research report 1957). But see Phillips, Rules of Law or Laissez-Faire in Commercial Arbitration, 47 HaRv. L. Rev. 590, 609 (1934). The folklore of labor arbitration-among arbitrators, commentators and participants on both sides-is particularly averse to recourse to the courts to challenge awards.

Especially throughout the mid-West does recourse to the courts re arbitration seem to be an extreme rarity. See Howard, Labor-Management Arbitration: "There Ought to be a Law"or Ought There? 21 Mo. L. REv. 1, 16-17 (1956).

However, in such cases as do get to court, the batting average for awards which remain unscathed is low. See McDonald, Stein and Taphtz, Management Rights and the Arbitration Process, N.Y.U. Eighth Annuad Conference on LABor 346 (1955) ; Procedural and Substantive Aspects of Labor-Management Arbitration, 12 ARB. J. (n.s.) 67 (1957); 6 WIIIISTON, Contracts § 1929A (rev. ed. 1938); Isaacs, Two Views of Commercial Arbitration, 40 HaRv. L. REv. 929 (1927).

2 No one has yet suggested a way of foreclosing the courts completely from any contact with contested awards, nor ways to eliminate the possibility of contest. For a suggestion that no statutory review proceeding is desirable see Howard, Labor-Managenent Arbitration: "There Ought to Be a Law"-Or Ought There? 21 Mo. L. Rev. 1 (1956).

3 It was never clear as between law courts and equity courts exactly which court had "jurisdiction," whether "exclusive" or "concurrent," over particular grounds for review of awards, and, under the codes, whether the action "sounded" in law or equity. But it was at least clear that the courts collectively would supply the answer. 
judgment on awards, or to vacate, modify or correct them in accordance with the statutory grounds. ${ }^{4}$ The extent to which this legislative answer has in fact preempted or should or could preempt the courts from any substantive participation in resolving the issue is the subject of this discussion.

Non-statutory vacation or modification of awards was traditionally had in equity. ${ }^{5}$ Questions arising under the statutory scheme are, therefore: (1) Are the statutory grounds to be considered as tapping ancient heads of equity jurisprudence with full capacity to grow and develop or are they frozen to the specific contents which those grounds had achieved at the time they were stamped into the statute? (2) Is the court which sits on the statutory motions-i.e., the motions court-a plenary court with general equitable discretion or is its function a "merely ministerial" " duty to apply the statutory grounds woodenly? These questions go to the "jurisdiction" or to the "power" of the motions court, depending upon whether you like your jargon "legal" or "sociological".7 If "equity" is translated as policy discretion, then terms have been matched for the doctrinal analyst and the realist as far as seems possible.

The goal is a full measure of finality for arbitration awards, yet it seems an inescapable conclusion that this cannot be achieved by language alone, statutory or otherwise. Words are not self-executing. Even if a judge be not disposed to do violence to statutory intent through "interpretation," he must, if he is to decide the case at all, do some interpreting in the process of deciding whether and how to apply the statute. ${ }^{8}$ Even if it were desirable to freeze the idea content of various grounds to the exact contexts in which they had already received judicial recognition prior to their embodiment in the statutes, no one can say with much confidence just what was included and what excluded at common law. ${ }^{9}$

4 The first "modern" arbitration statute, the New York Arbitration Law, was enacted in 1920. N.Y. Sess. Laws 1920, c. 275 . Seventeen other states may be said to have followed suit. See note 74 infra.

5 "Direct" attack on an award is available at common law by bill in equity (or code action). The vahidity of the award may also become involved "at law." Some of the common law grounds for attack are "legal" and some "equitable"; grounds of both genesis are found in the statutes. See Jones, Judicial Review of Arbitral Awards-Common Law Confusion and Statutory Clarification, 31 So. CarIF. L. Rev. 1 (1957).

6 See note 12 infra.

7 I.e., (a) do the statutory motions vest the court with a "merely ministerial" jurisdiction or are they to be treated as "quick bills in equity" (see text at note 121 infra); or, if you prefer, (b) do the formal prescriptions embodied in the statute effectively control or prevent the exercise of a pohcy discretion by the motions judge?

8 Study has revealed, somewhat surprisingly, numerous learned and experienced arbitration experts, many of whom regard themselves as semantic "realists," urging wooden construc. tion of the statutory language. Apparently we are asked to make a wooden construction of language "just this once."

0 The statutory phraseology itself contains so many high-level abstractions as to allow a judge to reach his desired result however he visualizes his agency in the mediating process. There 
A further question arises: assuming universal agreement that a certain ground of attack is not reasonably includable within the ambit of any of the statutory phrases, is there then no further room for discretion? Must the award be judicially confirmed-regardless of consequences of policy factors involved? This is a tempting proposition-in view of repeated and unwarranted judicial invasions of the finality of the arbitrator's decision on the merits ${ }^{10}$ in ordinary cases-but one which ignores the reality that society in general or at least others than the parties who have consented to the arbitration may, occasionally, be affected by the result in a manner which requires some attention by a decision maker who is responsible to the general society and not merely to the parties themselves. Even if an award is viewed as being no more than a contract it is now a half century late to contend that, of itself, this factor bars the courts from any concern with the effects of the bargain. From the beginnings of "equity," courts have occasionally deviated from the common and statutory "law" when it seemed necessary after the pohicy behind the legal rule was carefully weighed against the equitable factors in the particular case.

Prevalent illusions that sometimes pose as formal authority or "rules" include the following: (1) if a statute providing for vacation of an award by a court specifies the grounds on which such jurisdiction is to be exercised, no grounds other than those specified can be entertained; ${ }^{11}$ (2) in the statutory post-award motions proceedings, the court's duties are merely

seems hittle likelihood, in fact, that any of the judges whom this writer interviewed during this study has any intention of assuming a "merely ministerial" role in reviewing awards.

10 Of cases reported in the last 20 years in all of the states, those cases are rare indeed in which the court really seemed to disagree with either the factual or legal conclusions of the arbitrator, and yet confirmed the award. In the many cases in which the court confirmed the award with a strong statement about the finality of the arbitrator's decision on the merits, there is almost always some independent substantive treatment of the merits wherein the court indicates its agreenent with the conclusions reached by the arbitrator.

116 C.J.S., Arbitration and Award $\S$ iii (b) (1937). In none of the 23 cited cases was the issue substantially involved. See also, to the same effect, Stern v. Stern Co., 200 F.2d 364 (D.C. Cir. 1952) ; Hutto v. Jordan, 204 Miss. 30, 36 So. $2 d 809$ (1948) ; Anco Products Corp. v. T.V. Products Corp., 23 N.J. Super. 116, 125, 92 A.2d 625, 630 (App. Div. 1952); Westinghouse Air Brake Co. Appeal, 166 Pa. Super. 91, 97, 70 A.2d 681, 684 (1950); Loretta Realty Corp. v. Massachusetts Bonding and Ins. Co., 83 R.I. 221, 226, 114 A.2d 846, 848 (1955); cf. Crofoot v. Blair Holdings Corp., 119 Cal. App. 2d 156, 186, 260 P.2d 156, 172 (1953) and dissenting opinion of Justice Carter in Franklin v. Nat C. Goldstone Agency, 33 Cal.2d 628, 633, 204 P.2d 37, 41 (1949).

12 "Under statutes providing for the summary entry of judgment on an award, the power or duty thus imposed or conferred is a special ministerial one . . ." 6 C.J.S. Arbitration and Award $\$ 129$ (a) (1937). [In this connection] the court becomes charged with the ministerial duty of entering judgment on the award." Id. See also Ferguson v. Ferguson, 93 S.W.2d 513, 516 (Tex. Civ. App. 1936) ; Fortune v. Killebrew, 86 Tex. 172, 177, 23 S.W.976, 978 (1893) (discussed in note 112, infra). 
ministerial rather than judicial ${ }^{12}$-there is no equity power in the court; ${ }^{13}$ (3) where the language of a statute is clear and unambiguous, there is no room for interpretation. ${ }^{14}$

These "rules" are not rules of operative effect; they are dicta which float perennially through the language of the law on this subject, rarely if ever coming to rest at the point of decision. It does not seem wise, candid or necessary to incant the magic words when the policy implicit in them is not in fact apphed, either because it is not fundamentally at stake or because it has really been superseded in the eyes of the decision maker by some even more urgent general policy. There is, however, a hard core of policy in the idea underlying some of these rules and it would be a poor brand of "equity" or discretion which would destroy it.

Such "rules" may be placed in context by studying the actual flow of decisions. Addressed here is the preliminary question of the nature and power of the motions court itself, not what the court will or should do with its power in most cases. ${ }^{16}$

\section{GROWTH OF EQUTTY IN THE STATUTORY POST-AWARD MOTIONS}

If some measure of policy discretion or "equity" in the courts be desirable or, in any event, inevitable in reviewing statutory awards, should the equity be wielded by only the motions court, the "regular" courts, or both? If the "regular" courts are to have any office here regarding statutory awards, should it overlap conpletely the grounds cognizable in the statutory motions court or be limited to matters beyond the competence of the statutory court?

However broad the judicial review ultimately permitted, it seems desirable to confine it to one unified judicial proceeding, readily available soon after rendition of the award, so that all doubts as to the award's finality may be quickly and conclusively resolved. Whichever tribunal is to entertain that final, conclusive proceeding should be competent to consider all the pohicy factors relating to awards with which the judicial arm of government is permitted to concern itself. Indicated goals are, therefore, (a) the vesting of the statutory motions court with whatever judicial discretion is to exist in the premises and consequently (b) the complete exclusion of the

13 No court has been found to have said this expressly, although the idea is implicit in some opimions, e.g., LeBlanc v. Beard Paper Co., 320 Mich. 632, 32 N.W.2d 73 (1948); Matter of Martin Weiner Co. and Fred Freund Co., 3 App. Div.2d 34I, 155 N.Y.S.2d 802 (1st Dep't 1956).

1450 Ax. Jur., Statutes, §225 (1944); 2 Sutherrand, Statutory Construction $\$ 4702$ (3d ed. 1943) (said to be the rule, although criticized-but not enough).

15 The treatment is descriptive, except where goals are specified expressly, and implies no approval of all the "equity" described. 
"regular" courts from any review of awards; ${ }^{16}$ in other words, if the courts are to wield any "equity" at all, the preference should be for what might be called "equity in the statute" rather than for "equity behind the statute."

\section{A. The Trend of Decisions}

The arbitration statutes of many states expressly provide for the retention of "equity" or "jurisdiction" in their regular courts with respect to statutory awards, ${ }^{17}$ and courts have indicated that regular, non-statutory post-award actions are in order concerning statutory awards, especially when the grounds of attack are not specified in the statute.18

There is also discernible a definite trend toward vesting the statutory motions courts themselves with some degree of discretion based on policy or "equity." This trend, however, does not necessarily imply a corresponding reliction of "jurisdiction" by the regular courts, and it remains to be seen to what extent the regular courts will shed an overlapping or residual jurisdiction as the statutory motions courts assume a more plenary role. ${ }^{19}$

It seems that at some point in the judicial machinery protection will be given to equities unnamed or incompletely naned in the arbitration statute. The judicial developnent is in the direction of effectuating the equities in the statutory proceedings rather than leaving their protection to independent suits in equity behind the statutory schenve of enforcement.

This discussion deals primarily with the statutory motions to vacate, modify or correct, but the growth of equity in the statutory arbitration machinery generally ${ }^{20}$ will be noted too, for the courts do not distinguish

16 Another reason for excluding the regular courts from any participation in review of awards is that the substantive "Iaw" employed in those courts is badly confused by questions of practice, "sides" of court, juries, etc., raised by the elusive dividing line between law and equity. The statutory proceedings afford an opportumity to avoid the old doctrimal confusion as to the delineation of "law" from "equity." Decisions may then be made in terms of total policy alone, which ought to govern the grounds, evidence and practice on judicial review of awards, without reference to distinctions borne of the law-equity dichotomy. See Jones, Judicial Review of Arbitral Awards-Common Law Confusion and Statutory Clarification, 31 So. CaxIE. I. REv. 1 (1957).

17 E.g., IrL. Rev. Stat. c. 10, § 13 (1957); Ky. Rev. Star. \$ 417.018 (1956); Mrch. CoMP. I AWS $\$ 645.22$ (1948); MIsS. CODE ANN. $\$ 297$ (1942); VA. Code $\$ 8-506$ (1950); W. VA. Code ANN. $\$ 5502$ (1955). The pertinent provision in the Michigan arbitration statute, which is typical, is set out in the text at note 38 infra.

18 Columbian Fuel Corp. v. Warfield Natural Gas Co., 72 F. Supp. 839, 841 (S.D. W.Va. 1947) ; Acme Cut Stone Co. v. New Center Development Corp., 281 Micl. 32, 274 N.W. 700 (1937); Goldstem v. International Ladies' Garment Workers' Umon, 328 Pa. 385, 196 Atl. 43 (1938) (special Pennsylvania statute limits motion court to confirming awards that could be judgments at law). See also Adam's Adm'r v. Ringo, $79 \mathrm{Ky} .211$ (1880).

19 However, see notes $40-42$ infra, and related text, for an indication that the door may now be closed in New York to equity behind the statute.

20 One may well inquire as to the effect of enactment of an arbitration statute on equity jurisdiction generally. Standard works on equity and statute law reveal little which is lelpful for our problem. If there is any coubt as to whether the statute was intended to pre-empt the 
sharply among the various statutory arbitration proceedings ${ }^{21}$ with respect to the question of equity in the presence of statute. ${ }^{22}$

Of the many courts that refuse to stamp out equities not specifically named in the statutes, some still feel safer in referring the equity bearer to

field, it will be held not to do so, and equity will expound the statute or operate behind it. Where a court does find that a statute was intended to occupy a field completely, a number of theoretical problems arise on which there is little case law or text authority. No case has been found where a statute was held to have pre-empted a field and yet been lield to have in fact left some substantial equity without protection (except, of course, where the statute clearly indicated that such "equity" was intentionally and manifestly excluded because its recognition was against public policy). However, were such a situation to arise, it would be pertinent to consider the following:

On the power level: Any constitutional protection of the "equity" would have to be complied with, of course, notwithstanding the statute. Broad constitutional requirements, such as due process, might be lield to occupy the rest of the field and thus embrace the equity. This was broadly hinted at by the New York Court of Appeals in Schafran \& Finkel, Inc., v. M. Lowenstein \& Sons, Inc., 280 N.Y. 164, 19 N.E.2d 1005 (1939). And in a state, as for example New York, where the constitution (N.Y. CoNsr. Art. VI, $\$ 1$ ) is the source of equity jurisdiction in the courts, the courts retain power to sustain the neglected equity against the statute (assuming that it can't "find" its way into the statute).

On the policy level: Where the legislature has indicated its intent to exclude an equity, the courts generally follow that expression in the exercise of their equity discretion, as a matter of policy, and as a matter of power, too, where the equity jurisdiction has no constitutional basis. A large part of the inquiry, therefore, concerns statutory intent, rather than equity power vel non. Where no constitutional equity power prevents it, it is preferable to construe the arbitration statute as designed to give the right to complete relief, including the equitable relief in question, in the statutory proceeding, rather than to hold that the equitable right must be sustained in a separate "plenary" suit. Cf. In re Worcester Silk Mills Corp., 50 F.2d 966 (S.D.N.Y. 1927). Having merged equity and "law," we ought not now to be faced with the spectre of separate equity and "statute." Complete relief in the statutory actions will avoid multiplicity of suits and effectuate the purpose of both the code merger statutes and the particular procedural statutes in question. For whatever help it offers, there is the assurance of SUTBERLAND, StatuTORY CONSTRUTCTION $\$ 6005$ (3d ed. 1943) that modern courts have shown an extreme willingness to extend the operation of procedural statutes on the basis of analogy.

21 E.g., Kulukundis Shipping Co. v. Amtorg Trading Corp., 126 F.2d 978 (2d Cir. 1942) (motion to stay action pending arbitration); Finsilver, Still \& Moss, Inc. v. Goldberg, Maas \& Co., 253 N.Y. 382, 171 N.E. 579 (1930) (action to enjoin enforcement or direct jury trial on issue of existence of arbitration contract); cf. Schafran \& Finkel, Inc. v. M. Lowenstein \& Sons, Inc., 280 N.X. 164, 19 N.E.2d 1005 (1939) (action to enjoin enforcement).

22 But see Kulukundis Shipping Co.v. Amtorg Trading Corp., 126 F.2d 978 (2d Cir. 1942), in which Frank, J., for the court, distinguished between relief under $\$ 4$ (motion to compel arbitration) and $\$ 3$ (motion to stay action pending arbitration) of the United States Arbitration Act, 61 Star. 669 (1947), 9 U.S.C. \$§ 1-14 (1952), calling the former equitable in nature but the latter not. However, the relief sought under $\$ 3$ was granted in the case, because the conduct (alternative pleading) of the party seeking it was not inequitable. The Kulukundis case was one in admiralty where the body of law adninistered is special and not co-extensive with substantive equity (cf. Schoenamsgruber v. Hamburg American Line, 294 U.S. 454 (1935)) although Congress has the power to make it so. Marine Transit Corp. v. Dreyfus, 284 U.S. 263 (1932). In Hudson Lumber Co. v. United States Plywood Corp., 181 F.2d 929 (9th Cir. 1950), a non-adiniralty case, it was held that $\$ 3$ relief, is in effect, an injunction. STURGEs, CASES oN ARBitratron LAw, 295 (1953 ed.). To like effect: Wilko v. Swan, 201 F.2d 439 (2d Cir.), rev'd on other grounds, 346 U.S. 427 (1953); International Umion of United Furniture Workers v. Colonial Hardwood Flooring Co., 168 F.2d 33 (4th Cir. 1948); and Gatliff Coal Co. v. Cox, 142 F.2d 876 (6th Cir. 1944). 
an independent suit in equity, behind the statute, rather than to recognize equity in the statutory proceedings. ${ }^{23}$ However, most courts seem to be feeling their way, either cautiously or blindly, toward the latter approach, ${ }^{24}$ and many are now openly exercising equity power in the statutory proceedings. The result is achieved in various ways - most frequently by straining the statutory language, ${ }^{25}$ by iguoring the question entirely, ${ }^{26}$ or, in a few cases by frankly embracing the position. ${ }^{27}$

\section{B. Equity Behind the Arbitration Statute}

Three not too recent cases illustrate a preference for equity behind the statute.

In Columbian Fuel Corp. v. Warfield Natural Gas Co., ${ }^{28}$ a federal district court in West Virginia had before it an action on a common law award. The defendant moved to dismiss on the ground that the arbitration and award were statutory and could not be enforced in a regular suit in equity. The court held that it was a common law award and that the suit in equity was proper. The court went on to say that there can also be a suit im equity to enforce a statutory award where it is shown that the "remedy at law"meaning statutory enforcement-may not afford complete and adequate relief. ${ }^{29}$

In Goldstein v. International Ladies' Garment Workers' Union, ${ }^{30}$ the Pennsylvania Supreme Court reversed the statutory confirmation of a

23 E.g., Columbian Fuel Corp. v. Warfield Natural Gas Co., 72 F. Supp. 839 (S.D.W.Va. 1947) ; compare Acme Cut Stone Co.v. New Center Development Corp., 281 Mich. 32, 274 N.W. 700 (1937) with Goldstein v. International Ladies' Garment Workers' Union, 328 Pa. 385,196 Atl. 43 (1938).

24 Pratt, Read \& Co. v. United Furniture Workers, C.I.O., 136 Conn. 205, 70 A.2d 120 (1949) ; cf. Regorrah v. Vigneau, 335 Mich. 35, 55 N.W.2d 164 (1952).

25 E.g., Matter of Kutsukian and Bossom, 270 App. Div. 396, 60 N.Y.S.2d 27 (1st Dept. 1946).

20 E.g., The Hartbridge, 57 F.2d 672 (2d Cir. 1932); Brown-Turner, Inc. v. Complete Machiuery \& Equipment Co., 5 App. Div. 2d 200, 170 N.Y.S.2d 689 (1st Dep't 1958); First National Oil Corp. and Arrieta, 2 App. Div.2d 590, 157 N.Y.S.2d 313 (2d Dep't 1956).

27 E.g., Koerner v. Leathe, 149 Mo. 361, 51 S.W. 96 (1899) ; Donato v. American Locomotive Co., 279 App. Div. 545, 111 N.Y.S.2d 434 (3d Dept. 1952) (dictum, semble); see also Matter of Albert, 160 Misc. 237, 288 N.Y. Supp. 933 (Sup. Ct. 1936), and consult Matter of Publishers' Association and Newspaper and Mail Deliverers' Union, 280 App. Div. 500, 114 N.Y.S.2d 401 (1st Dept. 1952).

2872 F. Supp. 839 (S.D.W.Va. 1947).

29 Id. at 842 . The court did not clarify whether the West Virginia arbitration statute (by which it considered the matter to be governed) was adequate or not. It did, however, say that the discretionary power of the court under the statute (meaning, apparently, in statutory proceedings as distinguished froin "plenary" independent action) was limited. The West Virginia arbitration statute concludes, "But this section shall not be construed to take away the power of courts of equity over awards." W. VA. CODE ANN. $\$ 5502$ (1955).

$80328 \mathrm{~Pa} .385,196$ Atl. 43 (1938). 
statutory award on the ground, among others, ${ }^{31}$ that an award providing for affirmative equitable relief ${ }^{32}$ could not be confirmed in statutory proceedings because the Pennsylvania arbitration statute ${ }^{33}$ expressly equated a statutory judgment on an award to "a judgment in an action at law." The reversal was without prejudice as to "other proceedings under the contract in controversy." ${ }^{35}$ The court explained what other proceedings it had in mind by recommending a "bill in equity" in which the court could specifically enforce an award or upon a proper showing enforce the obligation to the extent of a negative decree enjoining its breach. ${ }^{30}$ Here was express recogmition of equity behind the statute, although it was perhaps not quite clear that the court would have considered such an award, enforceable "upon a proper showing" in a suit in equity, as then being a statutory award.

In Acme Cut Stone Co. v. New Center Development Corp. ${ }^{37}$ after a statutory award had been confirmed in statutory proceedings, the Michigan Supreme Court permitted an independent bill in equity to vacate the award on grounds which the court felt were not covered by the Michigan arbitration statute. The court affirmed the dismissal of the bill by the court below only after giving full consideration to the merits of the equitable grounds contended for therein. The statute itself provides:

Nothing contained in this chapter shall be construed to impair, diminish, or in any manner to affect the power and authority of any court of chancery, over arbitrators, awards, or the parties thereto; nor to impair or affect any action upon any award, or upon any bond or other engagement to abide an award. $^{38}$

The court did not purport to construe this provision but simply quoted it, and then said without further reliance on the statute: "The determination of this case depends entirely upon the inherent jurisdiction of a court of chancery over the awards of arbitrators." 39

31 The chief ground was that the lower court had erroneously held itself bound by the arbitrator's findings of privity of contract.

32 Order to remove a factory, reemploy discharged employees and continue performance under a contract.

33 Pa. Stat. Ann. tit. 5, \$174 (Purdon 1930).

$34328 \mathrm{~Pa}$. at $393,196 \mathrm{Atl}$. at 47 . The case is therefore a special one and not authority for the proposition that arbitration statutes without this express limitation do not clothe the statutory court with full equity power.

$35328 \mathrm{~Pa}$. at $394,196 \mathrm{Atl}$. at 48.

36 Ibid.

37281 Mich. 32, 274 N.W. 700 (1937).

88 Mich. Consp. Laws $\$ 645.22$ (1948).

39281 Mich. at 43, 274 N.W. at 704. (Emphasis added.) To which Professor Sturges queries: "On this basis why should either party resort to statutory motion to confirm or to vacate tho award? Or are both statutory and common law procedures required finally to settle the validity of the award?" Sturges, Cases on Arbitration Law 54 (1953 ed.). It is noteworthy in this connection that the court did not deal with defendant's contentions that the statutory proceedings rendered the demial of vacation res adjudicata. Also undiscussed was defendant's argument that the statutory proceedings were an "adequate remedy at law." 
Here is express recognition by the court, and probably by the statute, of equity behind the statute; although the case would have been stronger for the proposition had the independent bill actually been successful and the award vacated.

On the other hand, recent cases in New York indicate that the door may now be closed in that jurisdiction to any equity behind the statute, at least to the extent that the same grounds may be availed of within the statute. ${ }^{40}$ It may be, however, that the ban is limited to independent actions to set aside or modify awards and is not intended to apply to actions to enforce awards or, perhaps, defend against them. In E.A. Bromund Co. v. Exportadora Affonso de Alburquerque, Ltda.., ${ }^{41}$ an action to enforce an award begun in the New York courts and removed to federal court, it was said that an award can be enforced by action as well as by statutory motion, according to New York law, if the parties did not agree that the statute was to be exclusive. ${ }^{42}$

A recent federal case held that there was no jurisdiction to entertain an action for a declaratory judgment against a statutory award. ${ }^{43}$ No indication was given as to whether this type of equity behind the statute would have been available in favor of the award.

A holding that there is equity behind the statute is not necessarily a holding that there is no equity in the statute, and vice versa. The total substantive question is whether there is to be any equity at all, beyond statutory language, whether in or behind the statute. The procedural question, however, is whether the entire matter may not be resolved and complete relief givn in the statutory proceeding rather than to require separate suits with resultant delay, expense and uncertainty.

\section{Development of Equity in the Statutory Motions to \\ Vacate, Modify or Correct}

\section{New York}

The courts in New York seem to have developed plenary equitable relief in the motions to vacate, modify and correct.

40 Donato v. American Locomotive Co., 283 App. Div. 410, 127 N.Y.S.2d 709 (3d Dept. 1954). This case seems to contradict the same court's prior suggestion (to the same plaintiff) in Donato v. American Locomotive Co., 279 App. Div. 545, 111 N.Y.S.2d 434 (3d Dept. 1952) that there would be some equity behind the statute.

Flora Fashions, Inc. v. Commerce Realty Corp., 80 N.Y.S.2d 384 (Sup. Ct. 1948) (civil action to set aside an award brought by a stranger to the award, dismissed; strong dicta denying equity behind the statute).

41110 F. Supp. 502 (S.D.N.Y. 1953).

42 Ibid., citing Sandford Laundry Inc. v. Simon, 285 N.Y. 488, 35 N.E.2d 182 (1941). It was said that "an award may not be attacked in a plenary action," in Abrams v. Macy Park Constr. Co., 282 App. Div. 922, 125 N.Y.S.2d 256 (1st Dept. 1953) (action to reform contract under which arbitration had been held, plaintiff having participated in the arbitration).

43 Mengel Co. v. Nashville Paper Products \& Specialty Workers Union, 221 F.2d 644 (6th Cir. 1955). 
The early decisions in the New York Court of Appeals, dealing with other motions in the statute, presaged this growth. ${ }^{44}$ And in the thirties, the New York courts felt their way toward recognition of equity in the motions to vacate, modify or correct. ${ }^{45}$

In Jacoborvitz $v$. Herson, ${ }^{46}$ a statutory award on which judgment was entered at special term in statutory proceedings was assumed to have been procured by intrinsic perjured testimony. Subsequently plaintiff brought a civil action on the award and judgment, defendant counterclaimed to vacate them both, and plaintiff moved to dismiss the counter claim. Special term denied the motion to dismiss squarely on the grounds that the previous statutory motion court had been without power to vacate, but that the court in this subsequent plenary action had inherent power to vacate, set aside or modify the statutory court's judgment in the interest of "substantial justice." The appellate division affirmed the decision and approved the grounds on which it was based.

44 Cardozo, J., in Berkovitz v. Arbib \& Houlberg Inc., 230 N.Y. 261, 130 N.E. 288 (1921), sustaining the constitutionality of the New York Arbitration Act one year after its enactment, stated that statutes which did (and he held that the arbitration act did not) "subvert historic traditions of dignity and power" (he was referring to the plenary power in law and equity vested in the New York courts by the state constitution) would be "condemned." And in Finsilver, Still \& Moss, Inc., v. Goldberg, Maas \& Co., 253 N.Y. 382, 171 N.E. 579 (1930), Cardozo, C.J., made it even clearer that he considered that equity resided in the statutory motion to compel arbitration, equating it to a suit for specific performance. N.Y. CIV. PrAc. ACT \& 3.

Schafran \& Finkel, Inc., v. M. Lowenstein \& Sons, Inc., 280 N.Y. 164, 19 N.E.2d 1005 (1939), allowed an independent suit in equity to enjoin entry of judgment on an alleged statutory award, where apparently enforcement of the statute according to its letter might have led to inequitable consequences. N.Y. CIv. PRAC. ACT $\$ \S 1458$ and 1462 (5) apparently operated to deny to one allegedly never privy to an arbitration contract any right, under the statutory proceeding to confirm or vacate, to raise the point of privity or any equities attendant upon plaintiff's failure to reply within 10 days to a letter from defendant demanding arbitration. Cranc, C.J., said that if the statute required such a drastic result, it would probably be unconstitutional or, at least "unequitable." ("Unequitable" in New York may be tantamount to unconstitutional under N.Y. Consr. art. VI, \&1). But the Chief Justice, fastening on N.Y. Crv. PrAC. ACr \$ 1448 (arbitration contracts "shall be valid, enforceable and irrevocable, save upon such grounds as exist at law or in equity for the revocation of any contract") said that the statute was not intended to exclude equity and beld that there was equity behind the statute. He did not say or hold, however, that there would not have been equitable relief given in the statutory proceedings had Schafran \& Finkel brought a statutory motion to vacate (they did not).

45 In Matter of Albert, 160 Misc. 237, 288 N.Y. Supp. 933 (Sup. Ct. 1936), in confirming on motion an award cast in the form of a mandatory injunction, the court expressly recognized itself as being a court of equity ordering an injunction.

In Matter of Shirley Silk Co. and American Silk Mills, Inc., 257 App. Div. 375, 13 N.Y.S.2d 309 (1st Dept. 1939) the appellate division liad before it a case wherein special term had, on cross motions to confirm and to vacate, and motion for appointment of a referee, ordered the appointment of a referee to take the arbitrators' depositions. The appellate division modified the order by cutting down the questions to be considered by the referec, eliminating inquiry as to the method of arriving at the award and as to the arbitrators' disregard to the submission, but nevertheless approved the appointment as so modified. Since the statute does not provide for a reference, this was an exercise of equity power unnamed in the statute.

46243 App. Div. 274, 276 N.Y. Supp. 816 (1st Dept. 1935). 
The New York Court of Appeals, in Jacobowitz v. Herson, ${ }^{47}$ unanimously reversed, holding that the counter claim stated no cause of action. The court said that a motion court's judgment on an award is just the same as the judgment of any other court: "We see no reason for treating judgments entered upon an award of arbitration differently from those entered after trial in an action." 48

It was not expressly stated that the statutory grounds to vacate were the equivalent of total equity power, but the opinion did spell out those grounds and indicate that they were felt sufficient. The court laid down the rule that the policy of New York not to set aside judgments for intrinsic perjury applied to judgments on awards procured by intrinsic perjury. It might be inferred from the opinion that the court was of the view that the motions court, in withholding relief by not vacating the award for intrinsic perjury, acted according to the New York policy as might a court dispensing the equity power of the state in any other proceeding.

In the early forties, the New York courts continued to exercise equity powers in statutory post-award motions without much express recogmition of the process, as before with a heavy overlay of "rules" about exclusive grounds and limited jurisdiction appearing in the opinions. ${ }^{40}$

The terms in which the attorneys' pleadings were couched in some of these cases indicated an expectation on the part of the bar, at least, that the post-award motions would be dealt with as being addressed to a court possessing equitable discretion. ${ }^{50}$

Beginning in 1946, the New York decisions more openly express the idea that statutory proceedings to vacate, modify or correct involve the full judicial power, and especially the "equity" power, of the state.

Matter of Feuer Transp., Inc., ${ }^{51}$ a New York Court of Appeals decision, was not a post-award proceeding; rather, it involved a motion to coinpel arbitration. It must, nevertheless, be regarded as placing a heavy foot upon the scales in favor of recogmizing equity in all parts of the statutory machin-

47268 N.Y. 130, 197 N.E. 169 (1935).

48 Id. at 135,197 N.E. at 171.

49 In In re E. A. Laboratories, Inc, 50 N.Y.S.2d 222, 225 (Sup. Ct. 1944), in statutory proceedings to vacate or modify an award, the court said, "The only grounds upon which an award may be vacated appear in section 1462 of the Civil Practice Act; among these are the reasons [here] urged." (Emphasis added.) The language following the semicolon renders the "rule" about the exclusiveness of statutory grounds dicta in the case.

In Bolton v. General Accident Fire \& Life Assur. Corp., 51 N.Y.S.2d 407 (Sup. Ct. 1944), aff'd sub nom. In re Bolton's Estate, 268 App. Div. 905, 51 N.Y.S.2d 762 (1st Dept. 1944), reargument granted sub nom. In re Bolton's Will, 294 N.Y. 966, 63 N.E.2d 595 (1945), afj'd, 295 N.Y. 734, 65 N.E.2d 563 (1946), the court left open the question whether an award can be set aside for grounds other than those enumerated in the statute.

50 E.g., In re E. A. Laboratories, Inc., 50 N.Y.S.2d 222 (Sup. Ct. 1944), wherein the motion to vacate or modify an award included a prayer "for such further relief as may be appropriate."

51295 N.Y. 87,65 N.E.2d 178 (1946). 
ery. The decision made no distinctions among sections of the act and its tone and thrust were strong. ${ }^{52}$

Several cases in this period indicate a willingness to make some very substantial modifications in awards in order to effectuate what is characterized as the arbitrator's "true intent" or "real judgment" as distinguished from what the paper award says. ${ }^{53}$ Typically this is done without any very serious pretense at analysis of the restrictive statutory language. The "rules" about exclusive statutory grounds and restricted statutory jurisdiction are frequently repeated, but as elsewhere, are in reality of little or no effect. ${ }^{54}$

Most recently, the trend toward recognition of "equity" and policy discretion in the post-award statutory machinery in New York has continued

52 The court, in the Feuer case, said: "[I]f arbitration is to be a working reality, all ... . questions can and should be decided in a single proceeding. A party may ask specifically for one kind of relief to which he may not be entitled, but may at the same time be entitled to some other relief. If the relief to which a party is entitled is not granted and he is remitted to a new proceeding, the purposes of the reforms intended by the Arbitration Law of 1920 would be defeated. Instead of relief from legal technicality, the parties to an arbitration are given delay and a surfeit of legal procedure. Proceedings of this kind are equitable in character, and the practice of equity as to relief should be followed. In equity proper relief is ordinarily granted when the facts warrant regardless of what may bave been asked for. . . 'It is a general rule in equity that the relief to be administered will be adapted to the exigencies of the case as they exist at the close of the trial.' That rule was well applied at Special Term upon undisputed facts." 295 N.Y. at 92, 65 N.E.2d at 180. (Emphasis added.)

53 To the extent that these "modifications" or "corrcctions" of the paper award are bont fide based on the court's perception of the arbitrator's true intent, they pose a truly difficult policy problem as to whether it is better-in the long run-to abide the injustice of an occasional paper award at variance with the decision actually arrived at by the arbitrator, or on rare occasions to allow proof of the "real award" intended and to effectuate that at the risk of upsetting the finality of awards generally.

To the extent that these modifications are simply based on the court's idea of what the award should have been, they are indefensible invasions of the arbitrator's autonomy.

54 In Matter of Morris White Fashions, Inc. and Susquehanna Mills, Inc., 295 N.Y. 450, 68 N.E.2d 437 (1946), the New York Court of Appeals was confronted with a very substantial modification of a statutory award (special term had raised a $\$ 1,500$ award to $\$ 9,000$ ). The court affirmed appellate division's reversal of tbe modification, but in doing so, apparently did not rely upon any of the restrictive language of the statutory grounds for modification or correction. Rather, the court appeared to stress substantial factors, in and out of the statute, and to disapprove the modification only because those substantial factors were not present, factually, in the case. The petitioner for the modification bad argued an "evident miscalculation of figurcs," under N.Y. CTv. PrAc. ACr § 1462-a(1). The court did not discuss the "evident" requirement or seem interested in it; nor did the court discuss other restrictive language in the statute, such as "not affecting the merits" or "matter of form" (N.Y. CIV. PRAC. Acr $\$ 1462-a(2)(3)$.) Thc court empliasized that there was no failure of intent in the award (without dealing with the position of "intent" in the statute, which might have limited it). With respect to miscalculation, the court preferred to speak of "error of computation unrelated to any exercise of judgment or discretion." 295 N.Y. at 456,68 N.E.2d at 440 (emplasis added). The italicized phrase is not in the statute but was supplied by the court; it lies at the heart of the major focus of equity's policy for modifying or vacating on the ground of mistake.

In Matter of Kutsukian and Bossom, 270 App. Div. 396, 60 N.Y.S.2d 27 (1st Dept. 1946), 
apace, somewhat more overtly. ${ }^{55}$ In this era, no less than in others, "equity" sometimes does violence to the arbitration process and "policy" is still an "unruly horse." 56

In some instances the motions court has expressly stated that it is acting pursuant to "equity" "67 " or "justice" 58 rather than to statutory authority.

One much noted "bête noire" 59 which illustrates both the plasticity of power in the motions court and its amenability to perversion, is Matter of Publishers' Association and Nezspaper and Mail Deliverers' Union. ${ }^{60}$ In that case employees struck in violation of a no-strike contract pledge. An arbitration was had and an award rendered for $\$ 2,000$ "actual damages" and $\$ 5,000$ "punitive damages." The "punitive" damages were not payable "unless and until" the arbitrators should find-at a later date-that the union had again violated the contract, and then were to be payable at the option of the Publishers' Association.

The publishers moved to confirm, and the union moved to vacate the punitive provision. Special term confirmed the award and gave judgment on it.

the court substantially corrected an award by adding $\$ 2,340.90$ to it. The court assured itself that it was not reviewing the "merits," because the statute forbade that. The "merits" restriction apparently does not prevent very substantial modification where based on equitable mistake.

In Modernage Furniture Corp. v. Weitz, 64 N.Y.S.2d 467 (Sup. Ct. 1946), the court on cross motions to vacate and to confirm an award, with no motion made to modify or correct, substantially modified the award, by changing an award from a warning to a finding that a discharge was justified.

65 Consider, for example, Matter of Publishers' Association and Newspaper and Mail Deliverers' Union, 280 App. Div. 500, 114 N.Y.S.2d 401 (1st Dept. 1952). See text opposite note 62 infra.

56 "[Public policy] is a very unruly liorse, and when once you get astride it you never know where it will carry you." Burrough, J., in Richardson v. Mellish, 2 Bing. 229, 252, 130 Eng. Rep. 294, 303 (C.P. 1824).

67 Donato v. American Loconıotive Co., 279 App. Div. 545, 111 N.Y.S.2d 434 (3d Dept. 1952). See note 40 supra.

58 In Matter of First National Oil Corp. and Arrieta, 2 Misc. 2d 225, 151 N.Y.S.2d 309 (Sup. Ct. 1956), the court vacated an $\$ 82,752$ award because of a miscalculation of figures, labelled "mistake" by the court, not apparent upon the face of the award (it required reference to the arbitration transcript and respondent's brief at the arbitration to bring the mistake to light. The court tried valiantly to pretend that the misake appeared on the face of the award, in feigned deference to the "rule" that mistakes must appear on the face). It was stated that "... the court is, therefore, constrained to vacate and annul the present award, not only under the provisions of the statute, but in the interests of justice as well." 2 Misc. $2 \mathrm{~d}$ at 234,151 N.Y.S.2d at 317. (Emphasis added.)

50 Another case so characterized, by Kharas and Koretz, Judicial Determination of The Arbitrable Issue in Labor Arbitration-Some Recent Developments, 7 SyRAcuse, L. Rev. 193, 198 (1956), is Matter of Western Umion Tel. Co. and American Commumications Ass'n, 299 N.X. 177, 86 N.E.2d 162 (1949). The decision was affirmed, in Matter of First National Oil Corp. and Arrieta, 2 App. Div. 2d 590, 157 N.Y.S.2d 313 (2d Dept. 1956), with no notice apparently being taken of the fact that equities unnamed in the statute were thereby being enforced. See also Matter of Cross \& Brown Co. and Nelson, 4 App. Div. 2d 501, 167 N.Y.S.2d 573 (1st Dept. 1957) wherein "natural justice" supphed the basis for relief in pre-award statutory proceedings. 60280 App. Div. 500, 114 N.Y.S.2d 401 (1st Dept. 1952). 
The appellate division modified special term's order and judgmentby reversing "so much" of the order and judgment as confirmed the punitive part and by vacating that part-and then affirming "as so modified."

It seems that the court has developed a method of substantially modifying and correcting awards in the exercise of a plastic equity power by utilizing its appellate power to modify lower courts' orders affirming awards instead of modifying the award directly in the teeth of the technical language of the New York Civil Practice Act Section 1462-a which provides for nodifications "not affecting the merits" and "in a matter of form." 11

An alternate device to the same purpose and effect is that of vacating part of an award, used by the court here.

The court, having fortified itself with the technical ground that the part which it "nodified" out of the award was bad on the legal and statutory ground that it was "indefinite and not final," went on to assert, "[I]n vacating part of the award, however, our decision is based on the broader ground that the allowance of punitive damages is not enforcible with the aid of judicial power, rather than on the absence of finality under the form of award." 62

The court asserted its policy power bluntly, and, although it did not quite, syntactically, state that the statutory notions constituted it a court of equity with power to go beyond the grounds enumerated in the statute for vacating, nodifying or correcting, or to wield general equity power over the arbitration and award it seems froin the court's behavior and its opinion that it considers the statutory language no obstacle to any equitable result it wishes to achieve. "[N]ot enforcible with the aid of judicial power," and other language in the opinion, ${ }^{63}$ are indicative of equity power.

The dissenters thought that in a case of nore extreme penalty it would be "time enough" to consider the court's right to refuse confirmation; ${ }^{04}$ apparently, with them, it too, was but a matter of degree.

Two recent cases $^{65}$ in the appellate division, however, indicate some limitations, at least, upon the exercise of the notions court's power and, indeed, contain very strong language denying the existence of any power in the motions court to act at all on grounds other than those expressly authorized in the statute. ${ }^{66}$

61 N.Y. Civ. Prac. AcT \$ 1462-a(2) (3).

62280 App. Div. at 507, 114 N.Y.S.2d at 408. (Emphasis added.)

63 "The court has always regarded itself competent to inquire whether the result that arbitrators have worked out has been consistent with the public and legal policy of the community." Id. at 505, 114 N.Y.S.2d at 406. (Emphasis added.)

$64 I d$. at 511,114 N.Y.S.2d at 411 .

65 Matter of Penco Fabrics, Inc. and Louis Bogopulsky, Inc., 1 App. Div. $2 d$ 659, 146 N.Y.S.2d 514 (1st Dept. 1955); Matter of Congregation Talmud Torah, Inc. and Feinstcin, 283 App. Div. 892, 129 N.Y.S.2d 868 (2d Dept. 1954).

66 I.e., an up-to-date repetition of the "rules" stated in the text at notes 11-14 supra. Theso "rules" were made part of the "ratio decidendi" by the courts in both cases and in that sense 
In both cases the motions court had made a modification which was not only substantial, but probably changed what the arbitrator had really decided. At least it seems that the motions court had declared as the arbitrator's an intent which the arbitrator had not himself contemplated. Here was no mere change of the paper award to effect the arbitrator's true but imperfectly expressed intent; here was a patching of the paper award to implement the court's intent, a practice fraught with danger to the arbitral process.

In one of the two cases, ${ }^{67}$ the court, after announcing that the court below was powerless to do as it had done, hedged a bit by adding that "in any event" the petition for modification had come too late. ${ }^{68}$

In both cases the motions court in fact had itself made a substantive decision on the merits of the underlying controversy, ${ }^{69}$ a procedure that seems both poor policy and contrary to the basic idea of the statute-at least, in the absence of factors much more urgent than those involved in the cases under discussion.

Despite apparent eddies ${ }^{69 a}$ in the tide, it seems reasonable to infer that New York has evidently arrived at a position of equity or discretionary power in the post-award statutory motions, the courts varying in the extent to which and the wisdom with which they will exercise it. ${ }^{70}$

are really not mere dicta. However, as is suggested in the following paragraphs of the text, the non-statutory factors advanced by the motions courts in those cases were far short of any very urgent general policy considerations, and both cases were attempts to change or affect not only the formal paper award but also the arbitrator's actually intended decision.

67 Matter of Congregation Talmud Torah, Inc. and Feinstein, 283 App. Div. 892, 129 N.Y. S.2d 868 (2d Dept. 1954).

68 More than three months after filing the award.

69 In Congregation Talmud Torah, Inc. v. Feinstein, 283 App. Div. 892, 129 N.Y.S.2d 868 (2d Dept. 1954), the court below, at special term, had left no doubt of its purpose to go the full distance in acting as an equity court in reviewing awards under the statutory motions. With no motion to modify or correct before it, it added to an award which granted severance pay to a rabbi a condition that he desist from serving as a rabbi in the community. The motion court declared that "it is the court's function to determine and declare the meaning and intent of the arbitrators" (citing New York City Omnibus Corp. v. Quill, 189 Misc. 892, 73 N.Y.S.2d 289 (Sup. Ct. 1947), aff d, 272 App. Div. 1015, 74 N.Y.S.2d 925 (1st Dept. 1947), which did in fact so hold). Congregation Talmud Torah, Inc. v. Feinstein, 124 N.Y.S.2d 252, 254 (Sup. Ct. 1953). (Emphasis added.)

The appellate division eliminated the motions court's modification. 283 App. Div. 892, 129 N.X.S.2d 868.

69a See notes 65-69 supra, and related text. See also Matter of Martin Weiner Co. and Fred Freund Co., 2 App. Div. 2d 341, 155 N.Y.S.2d 802 (1st Dept. 1956) (refusal to vacate award for arbitrator's admitted failure to grasp the issues; seeming insistance on exclusiveness of statutory grounds to vacate).

70 An early statement in point appears in Cohen, The Law of Commercial Arbitration and the New York Statute, 31 Y AIE L.J. 147, 150 (1921), wherein it is said that "instead of narrowing the jurisdiction of the Supreme Court [the arbitration statute] broadens it. It adds to its equity powers." 


\section{States Other Than New York}

In many states ${ }^{71}$ there is no "modern" statutory post-award proceeding similar to the New York model. In most of these states either the nature of the post-award proceedings or the broad scope of review permitted renders imapplicable any discussion of the factor of "equity" or policy discretion in the teeth of a statute which appears to preclude it; in most of those states plenary judicial review at some point is either expressly provided for or seems clearly to be contemplated. In practice, in the rare case ${ }^{72}$ which does get to court, the courts of those states generally exercise a broad and plastic equitable review ${ }^{73}$-very frequently to the detriment of the free functioning of the arbitration process.

Some eighteen states ${ }^{74}$ and the federal government may be said to have statutory post-award ${ }^{75}$ proceedings and grounds substantially similar to those in New York. Of these states, the de facto growth of equity in the statutory machinery itself, traced above in the New York cases, appears most pronouncedly in those states having a sufficient volume of judicial review to constitute a somewhat constant stream of decisions for observation. Both California and Connecticut are good examples, with a gradual development in each culminated recently by dramatic and important name cases $^{78}$ which bring the result sharply into focus. As in New York, the

71 E.g., Alabama, Arizona, Arkansas, Colorado, Delaware, Florida, Georgia, Iowa, Kansas, Kentucky, Maine, Maryland, Massachusetts, Nebraska, Nevada, New Mexico, Oklahoma, South Carolina, South Dakota, Texas, Vermont, Virginia, Washington. The statutes of Illinois, Minnesota and Tennessee are similar to New York regarding modification or correction of awards, but otherwise they do not seem to restrict review as tightly as does New York. In工. REv. STAx. c. 10, \$\$ 11-13 (1957); MinN. Stat. \$\$ 572.05-.07 (1953); Tenn. Code AnN. \$\$ 23-514 to -15 (1955).

72 Both arbitration and court review thereof are sporadic and isolated phenomena in most of the states under discussion.

73 E.g., Continental Milling and Feed Co. v. Doughnut Corp. of America, $186 \mathrm{Md} .669$, 48 A.2d 447 (1946); Sydnor Pump and Well Co. v. County School Board of Henrico County, 182 Va. 156, 28 S.E.2d 33 (1943). Consult also Glens Falls Ins. Co. v. Gulf Breeze Cottages, 38 So.2d 828 (Fla. 1949); and see Davidson v. S.S. Jacobs Co., 93 So.2d 731 (Fla. 1957).

74 California, Connecticut, Idaho, Indiana, Louisiana, Michigan, Mississippi, Missouri, Montana, Nevada, New Jersey, North Carolina, North Dakota, Ohio, Rhode Island, Utah, Wisconsin, Wyoming. Consult also statutes in New Hampshire, West Virginia, Oregon and Pennsylvania. New Hampshire (N.H. Rev. Stat. ANN. \$ 542:8 (1955)) and West Virginia (W. VA. CODE ANN. $\$ 5502$ (1955)) make express provision regarding "mistake." A thorough analysis of the various statutory procedures by Professor Sturges appears in KEIIOR, ARBITRATION IN Action, 217-346 (1941).

75 The eighteen states enumerated, note 74 supra, are not all entitled to be classed as "modern" except in respect to their post-award statutory procedures. And some of them exclude future disputes clauses or specific subject matter (e.g., labor) from their coverage-thereby diminishing the area included within their "modern" post-award machimery, E.g., N.C. GEN. STAT. \$§ 1-544 to 1-567 (1953); Wyo. CoMr. STAT. ANN, §§ 3-5601 to 3-5624 (1945).

76 Black v. Cutter Laboratories, 43 Cal. 2d 788, 278 P.2d 905 (1955), cert. dismissed in Black v. Cutter Laboratories, 351 U.S. 292 (1956); Local 63, Textile Workers Union, CIO v. Cheney Bros., 141 Conn. 606, 109 A.2d 240 (1954). 
courts of these two states typically refrain from any express acknowledgment of a general "equity" competence on statutory motions and reach the discretionary result reluctantly and with a most circumspect overlay of "rules" about the exclusiveness of the statutory grounds.

\section{California $^{77}$}

The California cases in the late forties were somewhat ambivalent, although some judicial inclination to exercise discretion beyond any express statutory authorization was revealed. Two cases vacated awards for "illegality," refusing to confirm awards in favor of parties doing business without a license, a ground not to be found in the statute. In one of those cases, Loving \& Evans v. Blick, ${ }^{78}$ the submission limited the arbitrator to an award in accordance with the law, but in the other, Franklin v. Nat C. Goldstone Agency, ${ }^{79}$ the submission was general, and the court rested its opinion openly on "public policy" alone..$^{80}$

In Consolidated Vultee Aircraft Corp. v. United Automobile Workers, ${ }^{\text {s1 }}$ the motions court confirmed an award amending a collective bargaining contract. A month later the court corrected its own order, nunc pro tunc, to include a "construction" of the award which eliminated a maintenance of membership clause. On appeal, the California Supreme Court lield that the motions court had "jurisdiction" to correct its own order-a device ostensibly different from correcting the award itself even though, thereby, the nominal "confirmation" of the award became in effect a cancellation of the award. ${ }^{22}$

However, in Sapp v. Barenfeld ${ }^{83}$ the Califorma Supreme Court reversed the two courts below it and upheld an award against the charge that the arbitrator had omitted, by mistake, to find regarding certain items. The

77 A recent and definitive article on arbitration in California is Feldman, Arbitration Law in Califormia: Private Tribunals for Private Government, 30 So. Carre. L. Rev. 375 (1957). A compreliensive earlier work is Kagel, Labor and Commercial Arbitration Under the Californic Arbitration Statute, 38 CaxrF. L. REv. 799 (1950).

7833 Cal. 2d 603, 204 P.2d 23 (1949).

7933 Cal. 2d 628, 204 P.2d 37 (1949).

80 Carter, J., dissenting in the Goldstone case, and the district court of appeals, which had affirmed the award (188 P.2d 60 (1947)), expressly objected to the court's exercise of discretion in the teeth of the language of CAT. CODE Crv. Proc. $\$ 1288$ that the award "must" be confirmed unless the specific statutory grounds of impeachment are present. $33 \mathrm{Cal} .2 \mathrm{~d}$ at 633 , 204 P.2d at 41 . The district court had cited 6 C.J.S., Arbitration and Award, $\$ 129$, to the effect that other jurisdictions with similar statutes had held that "if the statutory provisions have been complied with, ... the court becomes charged with the ministerial duty of entering judgment on the award." 188 P.2d at 63 . (Emphasis added.)

8127 Cal. 2d 859, 167 P.2d 725 (1946).

82 The court did not discuss the statutory grounds regarding modification, but noted that, anyhow, the whole case was jnoot since the contract had expired.

8334 Cal. 2d 515, 212 P.2d 233 (1949). 
court held the omission an implicit disallowance of those items. It is not clear, however, whether the court considered the arbitrator's error, if any, as having really been a mistake-in the sense of an inadvertent failure to consider an item-or a mere error in refusing to consider something which he did consciously apprehend. ${ }^{84}$ The court made no general statement denying the existence of discretion in the statute.

In 1954, the California Supreme Court refused leave to appeal from United States Plywood Corp. v. Hudson Lumber Co. ${ }^{8 \mathrm{r}}$ in which the district court of appeals had effectively snuffed out a latent "equity" by affirming confirnation of an award which allegedly-and, it seems, actuallydid not reflect the arbitrator's true intent or "real judgment." ${ }^{80}$ The district court refused to admit extrinsic evidence, the arbitration transcript, for the purpose of so showing. The award, "mutual, definite and final" on its face, was inviolable and, under the statute, was accorded more finality than it would have had at comnion law. The opimion included language which could be taken as a declaration that the statufory grounds are exclusive: "the merits of the award, either on questions of fact or of law, may not be reviewed except as provided in the statute." ${ }^{87}$ This is the strongest recent California case in which a potential "equity" not enumerated in the statute was actually denied effect.

In 1955, several major cases, highlighted by the celebrated case of Black v. Cutter Laboratories, ${ }^{83}$ revealed a definite implementation of naked policy and fluid "equity" in the statutory post-award machinery, albeit always accompanied by strained attempts to include the result within the written terms of the statutory formulae.

In the Cutter case, Doris Walker, in her job application, concealed the facts that she was a lawyer, a Phi Beta Kappa and a Communist. The company had known this for two years prior to discharging her. The arbitrators determined that her discharge was for union activity-she had become president of the union local-and ordered her reinstated. The superior court confirmed the award. The district court of appeals unanimously affirmed in an opimion which urged the finahity of awards but also included an independent policy argument in support of the award..$^{80}$ The court

\footnotetext{
84 Probably only the former would have been considered a ground for equitable relief at common law.

85124 Cal. App. 2d 527, 269 P.2d 93 (1954).

86 Paragraph 1 of the award decided that a certain method would be used to determino costs in the parties' cost plus contract; paragraph 2 awarded the buyer a credit for money paid for substandard lumber. Extrinsic evidence (the arbitration transcript) would have shown that the sum specified in paragraph 2 was arrived at by an accounting method other than the one decided upon in paragraph 1 , so that paragraph 1 was really inconsistent with paragraph 2 .

$87124 \mathrm{Cal}$. App. 2d at 530,269 P.2d at 95.

8843 Cal. 2d 788, 278 P.2d 905 (1955), cert. dismissed, 351 U.S. 292 (1956).

88 Black v. Cutter Laboratories, 266 P.2d 92 (Cal. App. 1954).
} 
recognized that some grounds for upsetting awards other than those enumerated in the statute might be available, including "illegality"-citing the Loving and Goldstone cases. ${ }^{90}$ It urged, however, that where the claim of "illegality" is not based on the violation of some statute but on vague public policy, the court should exercise its power to vacate "with restraint and only in the very clearest of cases." 91

The California Supreme Court reversed and in effect vacated the award. ${ }^{92}$ It treated the case as one involving policy questions about Communism, ${ }^{93}$ paying scant deference, realistically, to the nold of the arbitration statute or the enumerated grounds for vacating awards. The court, of course, verbalized the result in partly statutory terms, e.g., that the arbitrators had "exceeded their powers," 94 but there was no real reliance on the statutory grounds. Any attempt to make sense out of the statutory rationalization or to take the case at face value leads only to confusion so far as "arbitration law" is concerned. It simply was not treated as an arbitration case but rather as a Communist case, involving an open question of policy for the court to decide. ${ }^{95}$ The court even went so far as to rationalize its decision in part upon a reversal of the arbitrators' finding of fact, that the discharge was because of union activities ${ }^{96}$ a procedure considered as being beyond the accepted fornulae by even the most hostile of anti-arbitration judges.

The United States Supreme Court ${ }^{97}$ couched its decision to dismiss the writ of certiorari in terms of "no federal question." ${ }^{98}$ Apparent in the opinion is the policy orientation of the majority toward the Communist problem and toward the constitutional claims of the union. The dissent ${ }^{99}$ addressed this constitutional policy question explicitly.

From motions court on up, this case was in fact dealt with as raisnig a policy question transcending the immediate interests of the private parties involved and the mold of normal arbitration statutory review. Nothing is to be gained for arbitration by pretending otherwise. That the ultimate

즉

90 Notes 77,79 stipra.

91 266 P.2d at 101.

92 Black v. Cutter Laboratories, 43 Cal. 2d 788, 278 P.2d 905 (1955).

93 Relating primarily to the "legality" or validity of an award reinstating a discharged Communist employee and to Party membership as a ground for discharge from einployment.

$9443 \mathrm{Cal} .2 \mathrm{~d}$ at $790,278 \mathrm{P} .2 \mathrm{~d}$ at 906.

95 This was confirmed to the writer in a later interview with one of the justices concerning the case; in discussing the views of the majority and the dissenters for over half an hour, not one word was said concerning arbitration law (despite my frequent prompting) but the whole case was discussed as one involving Communist policy only.

$9643 \mathrm{Cal} .2 \mathrm{~d}$ at $808,278 \mathrm{P} .2 \mathrm{~d}$ at 917.

97 Through Mr. Justice Clark.

88 Black v. Cutter Laboratories, 351 U.S. 292 (1956).

99 By Mr. Justice Douglas, joined by Justice Black and Chief Justice Warren. 
decision may have been poor constitutional law does not mean that it was not properly a question for court determination. ${ }^{100}$

In another case at this time, Flores v. Barman, ${ }^{101}$ the award provided that the company did not have the right unilaterally to terminate a collective bargaining contract on a certain date. The company moved to vacate the award and the union moved to confirm. The motions court "modified" [!] the award by changing "does not have" the right to "does have" the right to terminate, ${ }^{102}$ with no mention of the statutory grounds for modification-which definitely do not include the ground that the court simply disagrees with the arbitrator's conclusion. Here was a drastic 180 degree reversal of the award on the merits, in the guise of "modification"; its effect was greater than that of a vacation, for here the court really took jurisdiction of and decided for itself the underlying controversy. The district court of appeals in affirming said that it was a "plain matter of law" for court determination and, as its statutory rationalization, the arbitrator had "exceeded his powers." 103

In Los Angeles Culinary Workers, AFL v. Stan's Drive-Ins., Inc., ${ }^{104}$ the district court of appeals again affirmed the exercise of plenary and plastic discretion in freely "modifying" an award-this time to patch it up and save it from a charge of vagueness. ${ }^{105}$

Griffith Co. v. San Diego College for Women, ${ }^{100}$ was a case involving an award in favor of a church-operated girls' college over a construction company. The girls' school won. The arbitrator had done several things, including getting outside legal advice, which could have sent the case either way on the issue of "misconduct"; the district court of appeals" ${ }^{107}$ held unanimously that the arbitrator was guilty of misconduct, primarily because it

100 I believe that the California court erred seriously in its policy decision (as did the United States Supreme Court on appeal when it held there was present in the case no fcderal question-another unconvincing jargonal rationale), but I think that this particular policy decision was one for the court to make.

101130 Cal. App. 2d 282, 279 P.2d 81 (1955).

102 Id. at 286,279 P.2d at 84.

103 Ibid.

104136 Cal. App. 2d 89, 288 P.2d 286 (1955).

105 The award had incorporated by reference ". . . the document in evidence in this arbitral matter ... ." The court said "the document" meant this document filed in court with the award. The award had provided for certain increases to become effective "... for tand [sic] during the year 1953 ;" the court "corrected" it to read as of "Jan. 15, 1953." The award provided for back wage payments "without undue delay;" the court changed it to "within 90 days." Id. at 92, 288 P.2d at 288-89. Here then were straight, substantial, substantive changes in the awardnot pursuant to any discernible intent of the arbitrator. The court ignored the restrictive clauses of the California statute, imposing limitations on the court's right to modify and stressed the final clause-as if it stood alone-directing the court to effectuate the intent of the award. The California Supreme Court denied a hearing.

10845 Cal. 2d 501, 289 P 2d 476 (1955).

107 Griffith Co. v. San Diego College for Women, 280 P.2d 203 (Cal. App. 1955). 
really disagreed with the basic conclusions of law in the award, but the supreme court held that there was no misconduct, after indicating that it agreed with the award on the merits. ${ }^{108}$

\section{Connecticut}

The Connecticut courts have not yet resolved the question of the nature and stature of the statutory post-award motions and of the power of the courts hearing them. There seems to have been some growth-and not all growths are benign-in the direction already travelled by New York, but this has been neither clear nor steady, although the recent and celebrated Cheney case ${ }^{109}$ seems to reveal a definite utilization of equity power in the statutory proceedings.

Some of the cases ${ }^{110}$ in the late forties may seem indicative of a restrictive concept of jurisdiction in the statutory post-award motions court, but this is not necessarily so, ${ }^{110 a}$ and the actual decisions did implement the power of the court on the motions whenever necessary and desired to save the motions from technical defects. It was declared ${ }^{111}$ that these proceedings are, in Connecticut (as they are in New York ${ }^{111 a}$ and in California ${ }^{111 b}$ ),

\footnotetext{
108 A careful doctrinal analysis of this case appears in Comment, 44 CaLTF. L. REv. 899
} (1956).

109 Local 63, Textile Workers Union, CIO, v. Cheney Bros., 141 Conn. 606, 109 A.2d 240 (1954). See text at note 115 infra.

110 E.g., Boltuch v. Rainaud, 137 Conn. 298, 77 A.2d 94 (1950); Yale \& Towne Mfg. Co. v. International Ass'n of Machinists, 15 Conn. Supp. 118 (Super. Ct. 1947) ; see also Local 445, Int'l Union of Wire, Mill and Smelter Workers, CIO v. The American Brass Co., 16 Conn. Supp. 137 (Super. Ct. 1949), wherein it is stressed that the statutory grounds of attack on an award are exclusive.

$110 a$ In both the Boltuch and Yale $\&$ Towne cases, supra, the court insisted that the postaward motions were not the commencement of ordinary civil actions, but the context of the cases makes it clear that the distinction drawn related only to required methods of service of process rather than to the jurisdictional power in the court. In those cases, the possible identification of the motions as other than civil actions served the purpose of saving them from pleas in abatement based on the fact that they had not been commenced by writ and service of summons as civil actions are commenced. It was said in Yale $\mathcal{E}$ Towne that the post-award motions were not new actions or proceedings, but only a stage in those already pending; it was observed that the short calendar provided by statute for these motions is not consistent with the conception of a newly commenced civil action. Yale \& Towne Mfg. Co. v. Int'I Ass'n of Machinists, 15 Conn. Supp. at 122.

However, it was nowhere said that the proceedings were not civil actions or not in civil actions; it was merely stressed that they were not the commencement of civil actions.

111 Said the court in Boltuch v. Rainaud, 137 Conn. 298, 301, 77 A.2d 94, 95-96 (1950), "... [P]laintiff's motion may come within such broad definitions of 'action' as are to be found in ... [cases cited]. It was nevertheless a special proceeding, authorized by statute ...." (Emphasis added.) Curiously enough, the court cited (without further development) the old Texas Killebrew case, infra note 112, wherein the label "special proceeding" was held to be a restrictive word.

111n Matter of Morris White Fashions, Inc. and Susquehanna Mills, Inc., 295 N.Y. 450, 68 N.E.2d 437 (1946).

111b Accito v. Matmor Canning Co., 128 Cal. App.2d 631, 276 P.2d 34 (1954). 
"special proceedings" 112_-leaving the door ajar, so far as terminology was concerned, to the development of plenary judicial power in the statutory motions court.

Other cases in the same era illustrate growing pains in evolving equity discretion in the post-award statutory motions. The movement has been from blind, hesitant groping ${ }^{113}$ toward the result to a somewhat more express

112 The courts have not often focused directly on the difference, or lack of it, between an ordinary action and these statutory motions; most of the courts that have directed attention to the distinction have termed the statutory proceedings- "special." This label bas not been very helpful, however, because the courts have varied as to whether the appellation "special" really makes a difference in the "jurisdiction" or power of the court in a proceeding so described.

Only one old case (in a state not having a modern post-award procedure) bas been found in which the court actually held to a difference in the effect upon the court's competence of statutory arbitration proceedings as distinguished from proceedings in an ordinary action, and not the proceedings but the jurisdiction of the court received the label, "special." In that case, Fortune v. Killebrew, 86 Texas 172, 23 S.W. 976 (1893), the Texas Supreme Court held that a judgment in statutory proceedings on an award could he later voided on "collateral attack" in a plenary suit, because the jurisdiction of the court in the statutory proceedings had been only "special" and the court's duty there only "ministerial rather than judicial."

No other instance has been found in which the label "special proceeding" has been held to be a "minus" word rather than a "plus" (or at least neutral) word-in terms of the plenary judicial power reposing in the statutory motions court.

Froin most of the other scattered discussion concerning the meaning of the term "special proceeding" emerges the idea that the term inplies certain advantages of speed and informality but no restriction of judicial competence, "equitable" or otherwise, to entertain and adjudicate any matter relevant to the validity of the award.

In an arbitration case under the federal rules, it was stated tbat the distinction between "action" and "special proceeding" is unnecessary. Stathatos v. Arnold Bernstein S.S. Corp., 202 F.2d 525, 527, n.1 (2d Cir. 1953). Recent strong statements in the California District Court of Appeals have (1) expressly rejected the notion that "special proceedings" means limited jurisdiction in the post-award motions court (Accito v. Matmor Canning Co., 128 Cal. App. 2d 631,276 P.2d 34 (1954)) ; and (2) stressed that a judgment on an award is to be treated the same as a judgment in an action (Los Angeles Culimary Workers, AFL v. Stan's Drive-Ins, Inc., 136 Cal. App. 2d 89, 288 P.2d 286 (1955)). The one New York case found to have discussed the distinction was emphatic in its insistence upon equating "special proceedings" with "actions" so far as dignity and power are concerned (Matter of Burge, 203 Misc. 67\%, 118 N.Y.S.2d 23 (Sup. Ct. 1952) (not an arbitration case)).

The force of the distinction seems to be spent in purely formalistic distinctions regarding the naming of the parties and pleadings and in according to "special proceedings" certain advantages in summary method of trial and ease of initiating process.

113 In Pratt, Read and Co. v. United Furmiture Workers, CIO, 136 Conn. 205, 70 A.2d 120 (1949), the Supreme Court of Errors refused to modify an award and used strong language against tampering with awards other than as expressly directed by the statute; however, the court did in fact stand for a little bit of "jurisdictional" growth in the motions court below. The court let stand (without comment) a motions court finding of the amount due for back pay even though the award itself had made no mention of back pay.

In Local 445, Int' Union of Wire, Mill and Smelter Workers, CIO v. The American Brass Co., 16 Conn. Supp. 137 (1949), in The Superior Court for New Haven County, a "plaintiff" (as the Connecticut courts call the moving parties under the statute) moved to confirm a statutory award. Defendant raised a special defense based on the Taft-Hartley Act and plaintiff moved to strike it out. The court (1) treated the special defense as though it were a properly made motion to vacate and (2) fully weighed its merits. Then, after deciding against the defense on its merits, it said that the defense vras bad because it was not included among the statutory grounds for vacating awards. 
recognition which made its first appearance in statements in other than postaward motions cases, indicating a recognition of the growth of equity in the statutory framework generally. ${ }^{114}$

In Local 63, Textile Workers Union, CIO, v. Cheney Bros., ${ }^{115}$ the award directing a reduction in wage rates was rather ambiguous and concededly beyond the submission in some particulars. The union moved to vacate; the company filed a cross-application to correct and confirm as corrected. The motions court vacated the award. The Connecticut Supreme Court of Errors reversed, ordering the court below to patch up the award, deleting here and construing there to eliminate the ultra vires phrases and to put some definite content into the otherwise vague award. As so doctored up, the award was confirmed. The dissent objected to this treatment as the "use of a legal meat ax." 110

\section{Other States}

The sporadic decisions in other states manifest the same judicial behavior: whenever really needed, an "equity" discretion is exercised at the point of decision-with heavy dicta restating the formulae concerning exclusive, wooden statutory grounds and restricted motions court jurisdiction. ${ }^{117}$

114 In Colt's Industrial Union v. Colt's Mfg. Co., 137 Comn. 305, 309, 77 A.2d 301, 303 (1950), the Connecticut Supreme Court of Errors, granting a motion to compel arbitration, cited with approval language to the effect that arbitration must operate with all of the flexibility which equity can give it. The language cited had appeared in the New York decision in the Feuer case (notes 51, 52 supra, and related text), also involving a notion to compel arbitration. In New York the growth of express recognition of equity in the statutory motions courts was effected first in other than post-award inotions. See text at note 44 supra.

A very recent Connecticut pre-award case goes quite far in giving equitable relief not provided for in the statute. Plaintiff brought a regular action to restrain allegedly partial arbitrators from continuing as arbitrators and for an order appointing new arbitrators. The court noted that no such premature relief is available under the statute but stated that it should be and granted the relief anyway. The court treated the regular action as tantamount to a statutory motion for the appointment of new arbitrators, so that here was equity in the statute as well as behind the statute. Gaer Bros. v. Mott, 144 Conn. 303, 130 A.2d 804 (1957).

115141 Conn. 606, 109 A.2d 240 (1954).

$110 \mathrm{Id}$. at $621,109 \mathrm{~A} .2 \mathrm{~d}$ at 247.

The case was argued in the supreme court, for the union by Governor Ribicoff (then Democratic candidate for governor), and for the successful company by Dean Sturges of Yale, a leading arbitration law authority and author of StURGes, COMOMERCIAT ARBtTratTon AND AwARDs (1930) and Sturges, Cases on Arpitration LAW (1953).

117 In each of the following cases, the courts in upholding awards laid down strong dicta about the exclusiveness of the statutory gronnds, but in none of them was there any very pressing extra-statutory "equitable" factor involved: Hutto v. Jordan, 204 Miss. 30, 36 So.2d 809 (1948) ; Anco Products Corp. v. T.V. Products Corp., 23 N.J. Super. 116, 92 A.2d 625 (App. Div. 1952); Westinghouse Air Brake Co. Appeal, 166 Pa. Super. 91, 70 A.2d 681 (1950); and Loretta Realty Corp. v. Massachusetts Bonding and Ins. Co., 83 R.I. 221, 114 A.2d 846 (1955). 
Some courts have effected equity in the statute and treated the motions courts as clothed with full equity powers-without discussing equity at all. ${ }^{118}$

An interesting old case that shows the nature of the movement from equity behind the statute to equity in the statute is Koerner v. Leathe ${ }^{110}$ in the Supreme Court of Missouri. When statutory steps were taken to confirm the award in that case, the defendant moved to vacate and demanded a jury on the motion. The court held that the defendant was not entitled to a jury, saying: ${ }^{120}$

This court, as early as ... [1848], held ... that by the common law' an award could not be set aside for any cause in a court of law;' that the relief was in equity prior to the enactments of the statutes governing awards. It is quite generally held that the statutory provisions are not exclusive but that the aggrieved party may still resort to equity .... But wherever the point now raised has been adjudicated, the ruling has been that on the issue of vacating or setting aside the award for fraud or partiality or on the statutory grounds resort must be had to the court, and on the issue thus raised the parties are not entitled to demand a jury.

It is noteworthy, however, that in the Hutto case the award had been modified in the court below because based on usury; the supreme court of Mississippi reversed and confirmed the award. Compare the Anco Products case with the earhier New Jersey case of Held v. Comfort Bus Lime, Inc., 136 N.J.L. 640, 57 A.2d 20 (1948), in which the court hinted strongly that it might occasionally vacate an award for reasons other than those enumerated in the statute (the court had mistake primarily in mind).

Recent dicta in other courts have indicated that other than statutory grounds might be considered. E.g., Campbell v. Automatic Die \& Products Co., 162 Ohio St. 321, 123 N.E.2d 401 (1954).

LeBlanc v. Beard Paper Corp., 320 Mich. 632, 32 N.W.2d 73 (1948), contains language which might conceivably be construed as denying equitable competence in the court on a motion to confirm, but should probably not be so interpreted. The award was vague and not final and directed the court to appoint a receiver to finish up the award. The motions court had confirmed and appointed the receiver, but the supreme court reversed, vacated the award and referred the proceeding back to chancery where the underlying controversy had been pending, refusing to be directed by the award to appoint a receiver. It was in that context that the court said: "We find nothing in the statutory arbitration proceeding that permits the appointment of a receiver and the continuation of protracted litigation." $320 \mathrm{Mich}$. at $644,32 \mathrm{~N}$.W.2d at 78 .

A later Michigan decision, Regorrah v. Vigneau, 335 Mich. 35, 55 N.W.2d 164 (1952), seems to contemplate an equitable discretion in the motions proceedings.

118 E.g., in The Hartbridge, 57 F.2d 672 (2d Cir. 1932) the United States District Court for the Southern District of New York had granted a motion to confirm an award "as a matter of course," because it felt that it had no discretion and that it bad no jurisdiction to entertain the statutory grounds to vacate, modify or correct in the absence of a motion for such relief. The circuit court reversed and flatly rejected the district court's view. The court held that there was discretion on the motion to confirm and that grounds to vacate could be entertained thereon. The court also said that the motions court judgment could of course be attacked on appeal, but that it was secure against "collateral attack."

119149 Mo. 361, 51 S.W. 96 (1899).

$120 \mathrm{Id}$. at $366,51 \mathrm{S.W}$, at 97. 


\section{The court also said: ${ }^{121}$}

[I] $t$ seems clear that the legislature intended the proofs on motions of this character should be taken by affidavits and that the appellate courts should hear and review the judgment as in equity cases.

This court in Tucker v. Allen ... held that the design of our statute was to encourage the adjustment of differences in a summary mode. While expressly preserving the right to resort to the courts of equity, the statutory method is itself what learned counsel aptly designates as " $a$ quick bill in equity."

Further evidence of the fluid character of relief made available within the statutory framework generally appears in those cases affording relief where no statutory motion exactly corresponding to the relief granted has been made, ${ }^{122}$ or where there is no statutory motion or provision for the type of relief granted. ${ }^{123}$

Having traced the development of equity in the statutes, it will be observed that some courts are not loathe to smother arbitration to deathwith "equity." Some opinions or decisions noting or actually giving effect to equitable factors in the case, conclude with a note of satisfaction that arbitration may not be as final, cheap or speedy as its adherents had supposed. ${ }^{124}$

\section{CONCLUSION}

As to the general problem, if the statutory motions do not embrace equity, then, in some cases, the remedy "at law," i.e., under the statute will be inadequate. Therefore, unless the courts find every equitable factor whicl arises to be within the terms of the statute-in whicl case, de facto, the statutory motions do embrace equity-an independent bill in equity

121 Id. at 368,51 S.W. at 97 (emphasis added). Compare the "quick bill" in the opinion in the text, stipra, with the "so-called 'short bill" " in the opinion in Mumm v. Jacob E. Decker \& Sons, 86 F.2d 77 (8th Cir. 1936). The court, in the latter case, refers to Rule 25 of the General Equity Rules of 1912 (28 U.S.C.A. following $\$ 723$ ) and states, inter alia, "Rule 25 sets forth what shall be contained in a bill in equity. A portion thereof is as follows: 'Third, a short and simple statement of the ultimate facts upon which the plaintiff asks relief, omitting any mere statement of evidence.'" Id. at 78.

122 Kulukundis Shipping Co. v. Amtorg Trading Corp., 126 F.2d 978 (2d Cir. 1942); The Hartbridge, 57 F.2d 672 (2d Cir. 1932); Giannopulos v. Pappas, 80 Utah 442, 15 P.2d 353 (1932).

123 See Note, 46 Colunc. L. Rzv. $847 \mathrm{n.11}$ (1946) as to disqualification of arbitrators prior to award.

124 Examples are Pierce Steel Pile Corp. v. Flannery, $319 \mathrm{~Pa} .332,179$ Atl. 558 (1935) and Sydnor Pump and Well Co. v. County School Board of Henrico City, 182 Va. 156, 28 S.E.2d 33 (1943) (a non-statutory arbitration).

The court in the Pierce Steel Pile case concluded: "The parties elected to submit their disputes to arhitration. This inethod of trying issues of fact and law is now solnewhat in fashion. It may well be that after other experiences such as the present litigants have had, it will be determined that the ancient method of trial in duly constituted courts of law is a more satisfactory way to settle controversies. This is for further experience to demonstrate." $319 \mathrm{~Pa}$. at 339,179 Atl. at 561 . 
can presently be maintained, assuming that the courts do not apply the "rule," as they seldom do in fact, that the statutory grounds are exclusive. ${ }^{125}$ This round-robin multiplicity of suits can hardly have been intended by the legislature and is not wise policy.

Under the federal rules or the code mergers, the distinctions between a bill or action in equity and the statutory motions are, at best, useless formalism. ${ }^{126}$ If there is to be equitable relief at all, it ought to be granted in the statutory proceedings.

The essence and purpose of private voluntary arbitration is defeated when reviewing courts participate in or alter the substantive decisions arrived at by the arbitrator. In recognition of this principle and the fact that courts are sometimes prone to transgress it in practice, the modern arbitration legislation has purported to define conclusively the grounds of judicial review and thereby to limit the role or "jurisdiction" of the reviewing court. This attempt to reduce the reviewing court to a merely "ministerial" function, devoid of all discretion, cannot be and is not being completely realized -whether we like it or not. The judges who apply or "interpret" this language have demands and expectations which are not himited to playing a purely mechainical role.

The trend toward effectuating equity in the statutory motions proceedings themselves rather than to require a "regular" action for that purpose behind the statute has been illustrated. Also noted was the practice of the courts to iterate the purportedly restrictive "rules" against judicial discretion in the very case in which that discretion was being exercised. The exposition of this growth has been primarily descriptive rather than teleological and by no means implies approval of all the "equity" 127 described.

Whatever equity is ultimately going to be brought to bear should be available in the statutory proceedings and consequently, unavailable in any so-called "regular" action behind the statute. More important-pro-arbitration realists might with profit abandon reliance upon illusory concepts such as "ministerial" courts and "exclusive grounds" in favor of more articulate argunients in specific cases directed toward convincing the judge that

125 For the idea that "equity will out" consider both old and recent cases in law courts wherein something like equity was dispensed in the legal actions. For example, see Wikoff v. Coxe, 1 Yeates 353 (Pa. 1794), and consult the recent New Jersey "Law" case, Held v. Comfort Bus Line, Inc., 136 N.J.L. 640, 57 A.2d 20 (1948) (dicta indicate that the court would act on grounds of "mistake" in the equitable sense, in a proper case). But compare Carhal Factors v. Salkind in New Jersey in 1950, 5 N.J. 485, 76 A.2d 252 (1950). Consult also STURges, ComarerCIAL ARBITRAtions AND AWARds (1930 ed.) § 361 .

126 Physically, and in content, the petitions or motions examined by the writer in the files of the Connecticut courts do not differ in any substantial particular from complaints initiating a civil action. The applications are for a hearing by the court and not merely for hearing by a named judge.

127 Most appeals to "equity" are but thinly disguised attempts to relitigate the merits of the arbitrator's decision on the law or the facts and slould be summarily rejected. 
the policy of finality in arbitration is more important generally and in the particular case than whatever other general policy seems to call for an interference with the award.

Frequent judicial interference with awards is a paralyzing blow to the healthy functioning of the arbitral process and a clear violation of the legislative purpose. However, in very rare instances it may be desirable for the court to exercise discretion-even in areas where the authority for it in the statutory language is admittedly thin or non-existent. Tlis would be where the general society or, at least, others than the parties who liave consented to the arbitration are affected by the result in a manner which requires some attention by a decision maker who is responsible to the general society; this, of course, involves public policy, a very troublesome question since "public policy," in a sense, can be said to be involved in every case reaching the courts and, indeed, in every case reaching an arbitrator. It does not seem possible, by way of limitation of the concept, to do more than to point out to the courts that it is one of our most basic public policies, by virtue of the arbitration legislation-as well as the judicially declared formal limitations on common law review-to allow final decisions on liuge and vital areas of fact finding and policy to rest with the non-governmental institution of arbitration.

The fundamental idea which needs recognition before arbitration proceedings will be accorded, in fact, the finality which formal authority assigns to them is that the parties not only choose a private decision maker but a private body of "substantive law" as well when they pick an arbitrator. So long as the controversy primarily concerns only the private context in which the parties conduct their operations, it seems appropriate to allow them to settle their disputes solely by reference to the local "living law" of that context. However, when the impact of the award substantially affects the general society, then the question must at least arise as to whether the circumstances require- to some extent-recourse to the law governing the general society. ${ }^{128}$

The trend toward "equity" or policy in the statutory motions proceedings is an accomplished plenomenon and in several important instances has received express recognition. Whether this seemingly inevitable equity power will be used, on the one hand, in good faith and judiciously, in order to further the goals of arbitration or, in rare instances, to harmonize thein with other urgently transcendant general policies, or on the other, as a mask disguising judicial redetermination of the merits of awards, stifling and crippling the arbitration process, remains to be seen.

128 Some implicit recognition has been given to this division of policy functions between arbitrator and court by virtue of the fact that our statutes have not really purported to do away entirely with the court's jurisdiction (i.e., they do not quite purport to be Norris-LaGuardia acts) but have laid out grounds and indicated a policy which favors arbitral finality. Considerations of stronger means or other institutional arrangements to register a vote of no confidence in the courts regarding review of awards are not within the scope of this paper. 


\section{California Law Review}

MEMBER NATIONAI AND WESTERN CONFERENCES OF TAW REVIEWS

Published Five Times Yearly by Students of the School of Law of the

University of California, Berkeley, California. Indexed in Index to Legal Periodicals and Public Affairs Information Service.

\section{BOARD OF EDITORS}

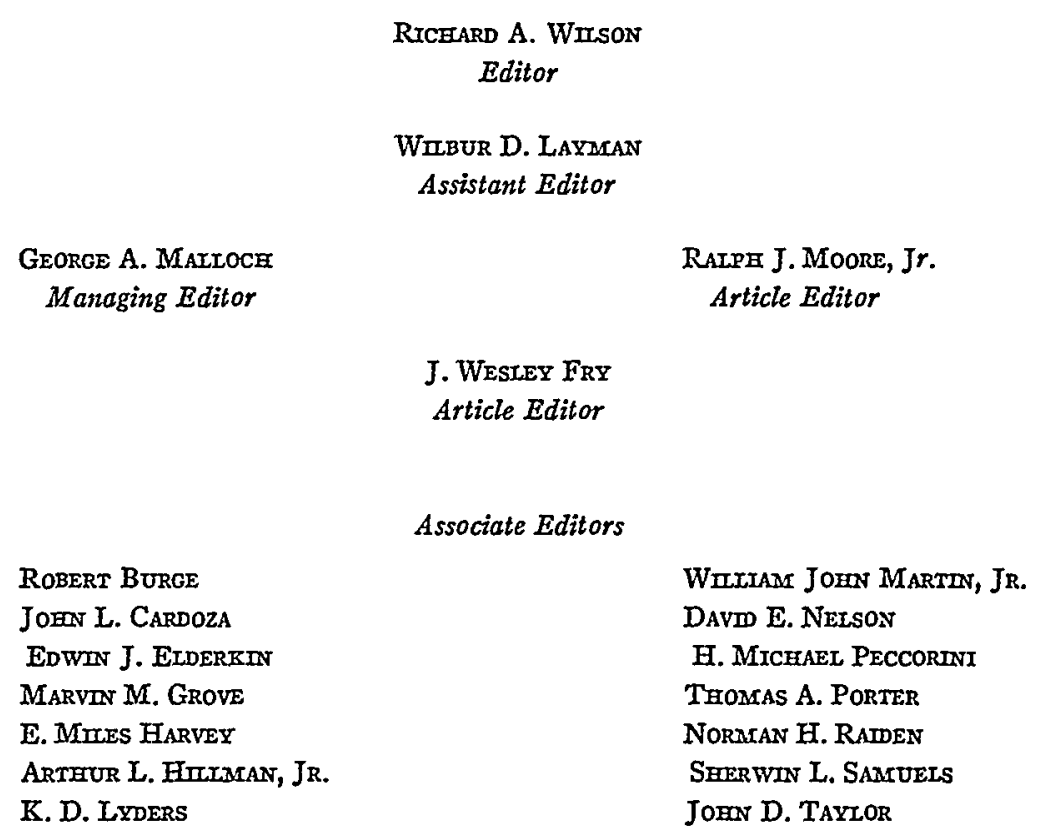

ANNe Hosman

General Secretary

EDWIN J. EIDERKIN

J. Westey Fry Marvin M. Grove

\section{Contributors}

ARThUR L. HITIMAN, JR. Wirbur D. Layman Thomas A. Porter 